Omni-Akuatika, 14 (2): 37-42, 2018
ISSN: 1858-3873 print / 2476-9347 online
Research Article
Journal Homepage: http://ojs.omniaquatika.net

\title{
Study of Proportions Seaweed Eucheuma cottonii L. and Cooking Time on Quality of Functional of Seaweed Dodol
}

\author{
David Hermawan $^{1}$, Warkoyo ${ }^{2^{*}}$, Noor Harini ${ }^{2}$, Claudia Jasmine ${ }^{2}$ and Okta Pringga Pakpahan ${ }^{2}$ \\ ${ }^{1}$ Department of Fisheries, Faculty of Agriculture and Animal Science, University of Muhammadiyah Malang, \\ J. Raya Tlogomas No.246, Malang, 65144, Indonesia \\ ${ }^{2}$ Departement of Food Science and Technology, Faculty of Agriculture and Animal Science, University of \\ Muhammadiyah Malang,Jl. Raya Tlogomas No.246, Malang, 65144, Indonesia \\ *Corresponding author: warkoyo@umm.ac.id
}

\begin{abstract}
Seaweed as a source of nutrition contains carbohydrates, protein, lipid and ash. Ones of ingredients that works for healthy were dietary fiber. Eucheuma cottonii seaweed contains carrageenan, which can act as a stabilizer, a material thickening, gelling agent, and emulsifiers. This research is aim to know the level of resilience Dodol with the proportion of seaweed and cooking time. The study was conducted using a randomized block design consisting of two factors. The first factor is proportions seaweed thickener composition, glutinous rice flour, rice flour (30:35:30, 40:25:20, 50:15:10), the second factor is cooking time $(20,30,40$ minutes) repeated three times. The observations parameter includes moisture content, ash content, protein, lipid, crude fiber, and texture. The research results showed that has interaction between the proportion of seaweed and cooking time. The proportion of seaweed and cooking time gives effect to the moisture content and the texture of dodol seaweed. The proportions give effect to the moisture content, ash, lipid, crude fibre, and texture while treatment cooking time gives effect to the moisture content, ash, protein, lipid, and texture of dodol seaweed. The best treatment is produced by treatment of $50 \mathrm{~g}$ of seaweed: $15 \mathrm{~g}$ of glutinous rice: $10 \mathrm{~g}$ of rice flour and 40 minutes cooking time with the result $62.10 \%$ moisture content, $3.32 \%$ ash content, $2.42 \%$ protein, $3.25 \%$ lipid, $5.20 \%$ crude fibre, $76.70 \mathrm{~N}$ texture.
\end{abstract}

Keywords: Proportion of seaweed, cooking time, dodol seaweed.

\section{Introduction}

Seaweed can be developed into various types of derivative products with high health value. Seaweed as a source of nutrients contains carbohydrates, proteins, lipid and ash which is largely a compound of sodium and potassium salt (Anggadiredja et al., 2006). Seaweed type Euchema cottonii L. as producer of carrageen have high fiber content. The dietary fiber content of seaweed Eucheuma cottonii reached $67.5 \%$ consisting of $39.47 \%$ insoluble food fiber and $26.03 \%$ water soluble (Kasim, 2004 in Tamaheang et al., 2017). Some processed products from seaweed are seaweed candy, seaweed jam and seaweed candy, besides seaweed can be processed into dodol product.

In this research, we used seaweed powder as carrageen made from seaweed species Eucheuma cottonii has the potential to serve as a healthful food provides a chewy texture. The composition of $1 \mathrm{~kg}$ dodol consists of $1 \mathrm{~kg}$ of glutinous rice flour, 1 to $1.3 \mathrm{~kg}$ of sugar, $0.8 \mathrm{~kg}$ of brown sugar, $1.5 \mathrm{~kg}$ of coconut milk, 3.5 litre of filtered water and including rice flour $1 \mathrm{~kg}$ brown sugar $0.5 \mathrm{~kg}$ to $0.8 \mathrm{~kg}$, coconut milk $1 / 2$ Itr, and half of the filtered water (Nasaruddin et al., 2012).

The dodol quality aspects divide two, first is ingredients composition, and the second is cooking time. An indicator of dodol quality is color, taste, texture, appearance and nutritional content. Those determined by cooking time and temperature (should below than $80^{\circ} \mathrm{C}$ ), mistake such as overcooked or underdone will make texture not "kalis", bad taste and color unenticing. Therefore, it is necessary to study the comparison of the amount of seaweed, glutinous rice flour and the cooking time 
treatment so that it can produce dodol with good characteristics and avalaible with the quality requirements of dodol according to (Indonesian Nasional Standard) SNI.

\section{Materilas and Methods}

Raw materials used in this research is the type of seaweed Eucheuma cottonii obtained from seaweed collectors in Sumenep, Madura. Glutinous rice flour and rice flour are obtained from Triple A food store in Malang, and $\mathrm{HCl}, \mathrm{H}_{2} \mathrm{SO}_{4}, \mathrm{NaOH}, \mathrm{Al}(\mathrm{OH})_{3}, \mathrm{Na}_{2} \mathrm{CO}_{3}$ chemicals are obtained from Toko Makmur Sejati Chemicals Malang.

The experimental design used was Randomized Block Design consisting of two factors with basic composition refers to Astawan et al., 2004 [seaweed(s): glutinous flour(gf): rice flour(rf) 30(s):35(gf):30(rf)]. Factor $I$ is consists of three group first is 30(s):35(gf):30(rf);second $40(\mathrm{~s}): 25$ (gf):20(rf); and third $50(\mathrm{~s}): 15(\mathrm{gf}): 10(\mathrm{rf})$. Factor $\mathrm{II}$ is the cooking time with the level of $20,30,40$ minutes. Observation parameters include moisture content (gravimetric method, AOAC 2005), ash content (Sudarmadji et al., 2003), protein content (Kjedahl method, Sudarmadji et al., 2003), lipid content (Soxhlet method,
Sudarmadji et al., 2003), texture / hardness test (textur analyzer, Ahmad et al., 2010), and crude fiber (AOAC, 2005).

Implementation of the research begins with the manufacture of seaweed porridge, and sugar solution. Then followed by mixing the sugar solution, seaweed porridge, glutinous rice flour, and rice flour, with a level according of treatment and cooking for 20-40 minutes (according to treatment). The process ends with printing and cooling to get the dodol seaweed to measure the test variables.

\section{Results and Discussion}

\section{Water Content}

The composition of water was increasing in line with increasing seaweed content. The water content in dodol have a lubricating effect between the particles and flow relatives unhindered, when the temperature increases, this effect becomes more significant (Chuah et al., 2007). Cooking time and temperature affect water flow content into dodol structure. The ideal water content of dodol seaweed ranges from $46.20-63.57 \%$, the complete results are presented in Table 1 and Figure $1 \& 2$.

Table 1.Average water content and texture of dodol seaweed due to different portion of materials and cooking time

\begin{tabular}{lcc}
\hline $\begin{array}{c}\text { Proportions seaweed(s): glutinous rice flour(gf): rice } \\
\text { flour(rf) and cooking times }\end{array}$ & $\begin{array}{c}\text { Water content } \\
(\%)\end{array}$ & Texture $(\mathrm{N})$ \\
\hline Proportions $30: 35: 30-20$ minutes & $47,17 \mathrm{~b}$ & $59,04 \mathrm{a}$ \\
Proportions $30: 35: 30-30$ minutes & $46,89 \mathrm{~b}$ & $62,34 \mathrm{~b}$ \\
Proportions $30: 35: 30-40$ minutes & $46,20 \mathrm{a}$ & $65,33 \mathrm{c}$ \\
Proportions $40: 25: 20-20$ minutes & $50,14 \mathrm{c}$ & $64,69 \mathrm{~b}$ \\
Proportions $40: 25: 20-30$ minutes & $50,23 \mathrm{~cd}$ & $67,70 \mathrm{c}$ \\
Proportions $40: 25: 20-40$ minutes & $50,47 \mathrm{~d}$ & $69,89 \mathrm{e}$ \\
Proportions $50: 15: 10-20$ minutes & $63,57 \mathrm{~g}$ & $67,76 \mathrm{~d}$ \\
Proportions $50: 15: 10-30$ minutes & $62,52 \mathrm{f}$ & $70,62 \mathrm{e}$ \\
Proportions $50: 15: 10-40$ minutes & $62,10 \mathrm{e}$ & $76,85 \mathrm{f}$ \\
\hline
\end{tabular}

Description: The value followed by the same letter means not significantly different based on Duncan test $a=5 \%$

The larger portion of the seaweed produces a higher water content. Thatis the larger the carragenan portion, and the stronger ofbinding potential of the water due to the greater the moisture content of the product. Glutinous starch contains high carbohydrate, that is in glutinous flour there are two compounds of amylose and amylopectin. The more concentration of glutinous flour used is the higher amylopectin fraction so that in the process of heating the material, the starch will swell and eventually break and the water holding capacity is lower (Suyanti, 2004). 


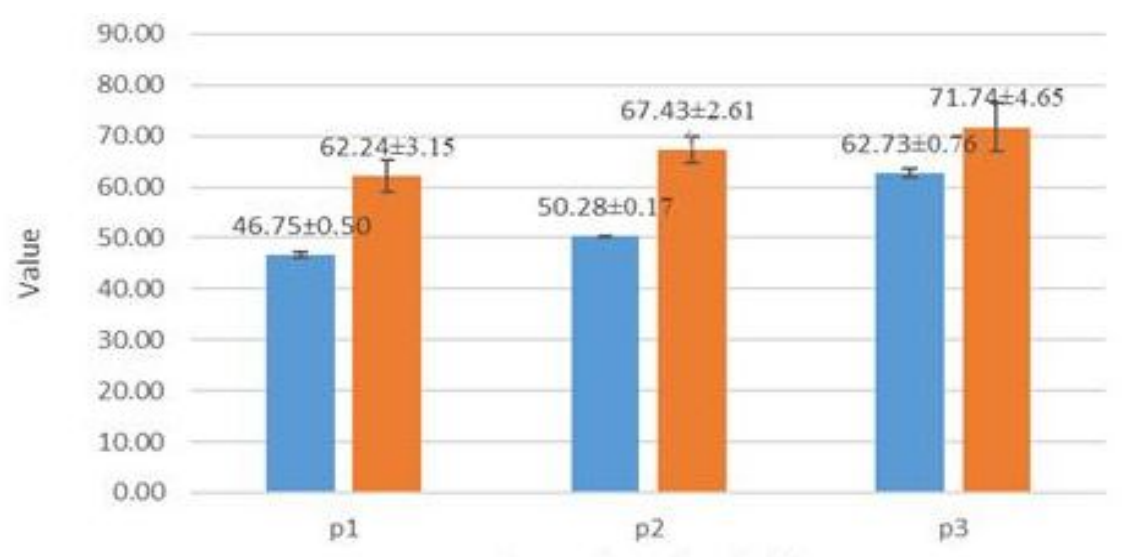

Figure 1. Water content and texture of dodol on different seaweed proportions.

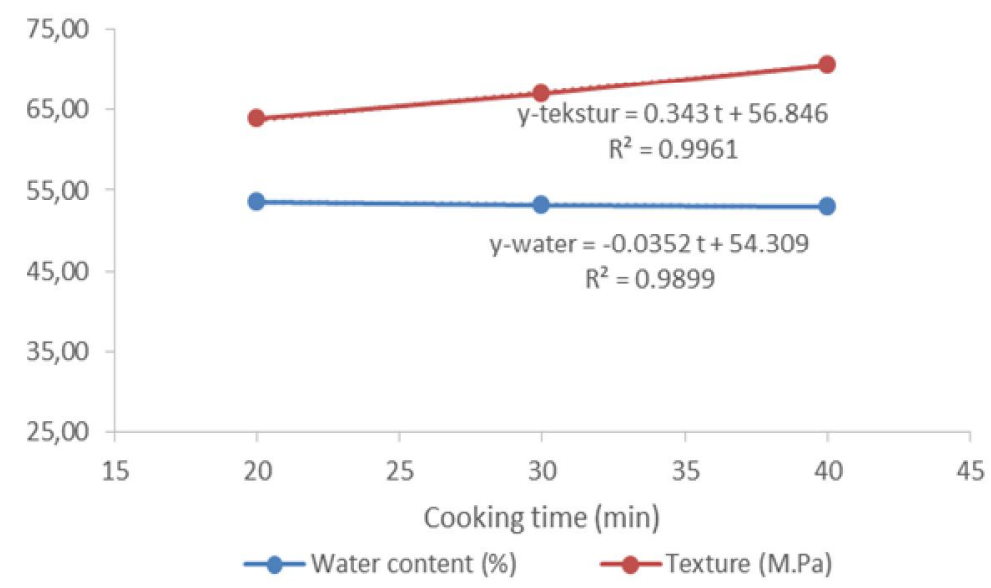

Figure 2. Water content and texture of dodol at different cooking time.

Texture

Texture of dodol gets harder with the added portion of seaweed, as well as the longer cooking time (Figures 1 and 2). The use of thickening in the manufacture of dodol, seaweed has a higher viscosity compared to glutinous rice flour. The higher texture value of dodol means its increasingly chewy. Changes in texture is possible because the seaweed contains carrageenan that has the ability or high water holding capacity. According to Hardian (1994 in Sembiring 2002) states the type of seaweed Eucheuma cottoni produce carrageenan that can react and function well with sugar, starch, gum and others. The formation of the gel is due to the double helix structure by the carrageenan polymer contained in the seaweed grass. The value of elasticity will increase if the product loses water.
Glutinous rice flour gives a chewy nature so as to form a dodol texture to be elastic. High levels of amylopectin make it very easy to gelatinize when added to water and obtain a heating treatment. This happens because of the binding of hydrogen with glutinous rice flour molecules (gel) that are chewy (Hartati, 1996). The old cooking time, causing the water content of the product is getting smaller, the harder the product, dodol texture is stronger, so to suppress the greater the energy required.

\section{Ash Content}

Ash content of dodol seaweed increases with portion of seaweed added and its decreases with cooking time added. The ash content of dodol seaweed of the this research can be seen in Table 2, and the over all picture is presented in Figures 3. 
Table 2. Mean of ash content, protein, lipid, and coarse fiber of dodol due to seaweed proportion and the effect of cooking time.

\begin{tabular}{ccccc}
\hline Treatment & Ash (\%) & Protein (\%) & Lipid (\%) & Crude fiber (\%) \\
\hline Proportion of materials & & & & \\
P1 (30:35:30) & $2,46 \mathrm{a}$ & $2,93 \mathrm{a}$ & $3,66 \mathrm{c}$ & $4,75 \mathrm{a}$ \\
P2 (40:25:20) & $2,67 \mathrm{a}$ & $2,83 \mathrm{a}$ & $3,37 \mathrm{~b}$ & $4,96 \mathrm{a}$ \\
P3 (50:15:10) & $3,55 \mathrm{~b}$ & $2,67 \mathrm{a}$ & $3,21 \mathrm{a}$ & $5,38 \mathrm{~b}$ \\
\hline Cooking times & & & & \\
T1 (20 min) & $3,13 \mathrm{~b}$ & $3,14 \mathrm{~b}$ & $3,34 \mathrm{a}$ & $4,86 \mathrm{a}$ \\
T2 (30 min) & $2,93 \mathrm{~b}$ & $2,70 \mathrm{ab}$ & $3,39 \mathrm{a}$ & $5,09 \mathrm{a}$ \\
T3 (40 min) & $2,61 \mathrm{a}$ & $2,64 \mathrm{a}$ & $3,51 \mathrm{~b}$ & $5,11 \mathrm{a}$ \\
\hline
\end{tabular}

Description: The value followed by the same letter means not significantly different based on Duncan test $a=5 \%$

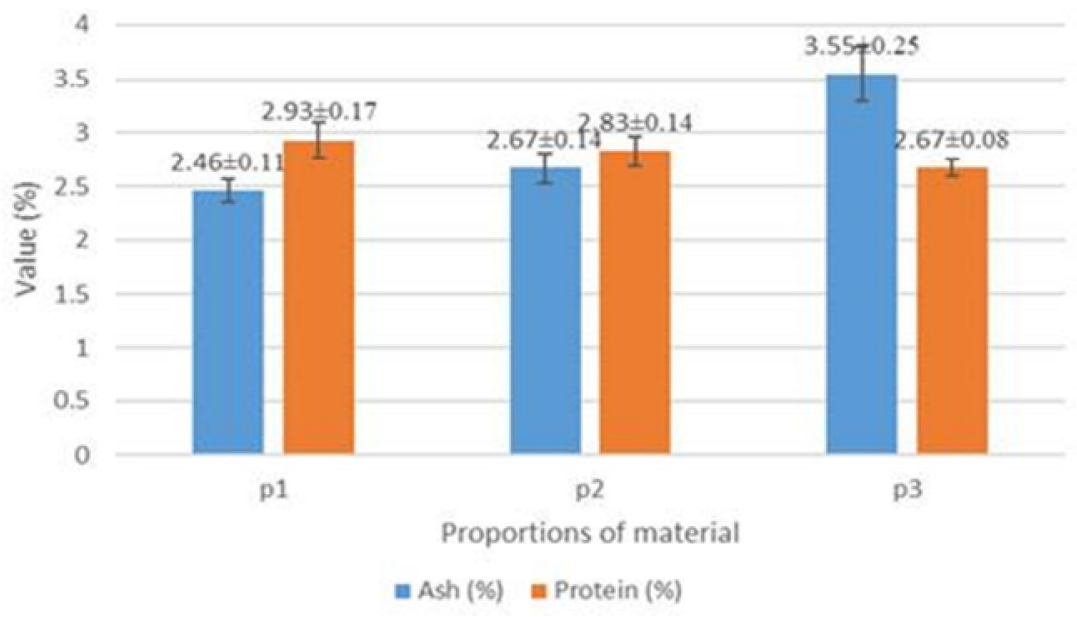

Figure 3. Ash and protein content of dodol at different proportion seaweed.

Seaweed contains a high mineral, ie $29.39 \mathrm{mg} / 100 \mathrm{~g}$ (KKP, 2012), so a large portion of seaweed in the manufacture of dodol seaweed causes ash content to be large. According to Gamman \& Sherington (1994) mineral content in seaweed can be reduced by the cooking process or processing, as a consequence ash content of dodol seaweed is reduced by the longer cooking time.

\section{Protein}

Protein content of dodol seaweed tends to decrease with portion of seaweed added because the portion of the glutinous rice reduced that contribute to the protein content. The protein content decreases with cooking time added. This can be seen in Table 2 and Figure 3.
Cooking time during processing can also cause a decrease in protein. The effect of warming on dodol can cause physical changes, flavor and taste and chemical composition (AOAC, 2005). Protein of dodol damage due to heating will affect the content of amino acids that correlate to the nutrient content consumed. In addition, according to Martos et al. (2011) the protein of the food is denatured when heated at $60-90{ }^{\circ} \mathrm{C}$ for an hour or more. In the long cooking time, the protein will be moredenatured.

Lipid

The resulting lipid content of seaweed dodol decreases with portion of seaweed added, and increases with cooking time added (Table 2 and Figure 4) 


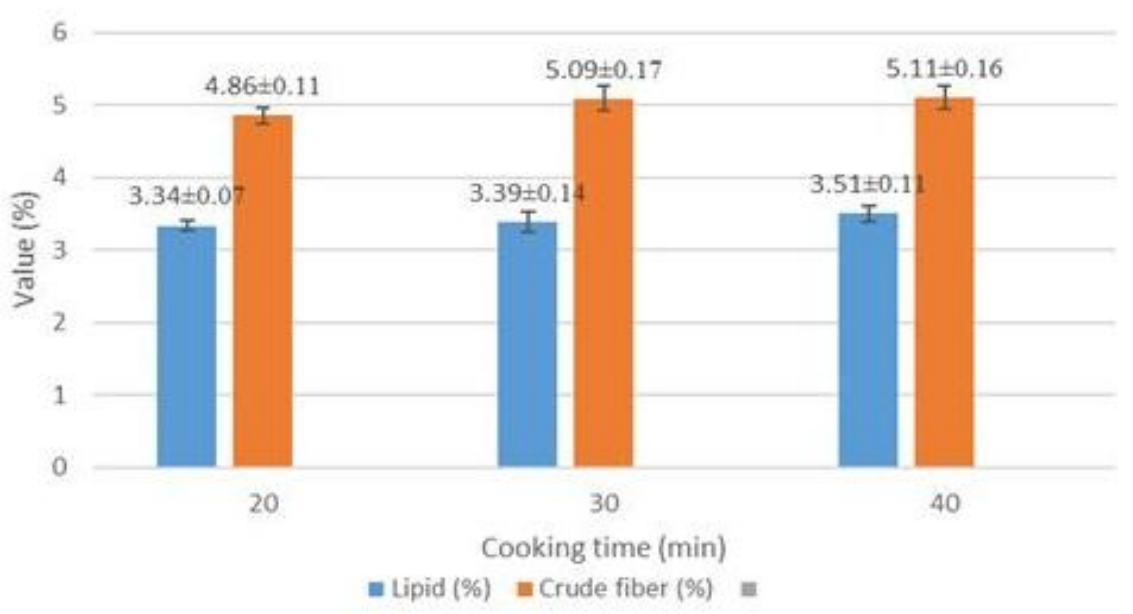

Figure 4. Lipid and crude fiber content of dodol at different cooking times

The difference of the results is due to the use of thickening materials, where the glutinous flour has a higher lipid content of $4 \%$ (Sudarsono, 1981), and compared to $0.4 \%$ seaweed lipid (KKP, 2012). The cooking time affects the product, the longer the cooking cause the decrease of dodol water content. The cooking time causes the water to evaporate so that the water content decreases. Water content affects the fat content of the resulting product, the higher the water content the lower the lipid content and the lower the water content the higher the lipid content of dodol seaweed.

\section{Crude Fiber}

High levels of fiber in dodol seaweed caused its from thickener seaweed containing high total fiber compared to thickener glutinous rice, in accordance with the Astawan et al. (2004) study, that seaweed is a plant that contains many fibers. Fiber content in seaweed has a high nutritional value compared with the fiber content of glutinous rice.

Cooking time affects to crude fiber content of dodol seaweed. And its associated to water content, that is lower the water content the crude fiber increases. According to Permana et al. (2015) in the fibers are formed intramolecular hydrogen bonds that cause a decrease in water solubility, since most $\mathrm{OH}$ groups do not form $\mathrm{H}$ bonds with water molecules. Aktas, and Gençcelep, 2006 study found the fiber will made water vapor more easily removed during heating it make water content becoming lower.

The high fiber of dodol seaweed is expected to provide rich content of essential minerals, protein, dietary fibre, vitamins $(A, B$, $C, E)$ and essential fatty acids (Mithril et al.,
2012). It also has a range of bioactive compounds, which may be beneficial in relation to immunity body system (Cooksley, 2007).

\section{Conclusion}

The proportion of seaweed and cooking time have an effect on quality of dodol seaweed. The increased proportion of seaweed affects to increase of water content, ash content, crude fiber, and texture of dodol seaweed. The cooking time treatment has an effect to content of water, ash, protein, lipid, and texture of dodol seaweed. The best treatment resulted from seaweed treatment 50 g: glutinous flour $15 \mathrm{~g}$ : rice flour $10 \mathrm{~g}$ and 40 minutes cooking time with $62.10 \%$ water content, $3.32 \%$ ash content, $2.42 \%$ protein, $3.25 \%$ lipid content, $5.20 \%$ crude fiber, and texture $76.70 \mathrm{~N}$.

\section{References}

Aktas, N.; Gençcelep, H. 2006. Effect of starch type and its modifications on physicochemical properties of bolognatype sausage produced with sheep tail fat. Meat Science 74, 404-408.

Anggadiredja, T., H. Purwantodan S. Istini. 2006. Rumput Laut. Penebar Swadaya. Jakarta.

AOAC. 2005. Official Method of Anaisys of the Association of Official Analittycal Chemist. Benyamin Franklin Station. Washingtin, D.C

Astawan, M., S. Koswara. Dan F. Herdiani. 2004. Pemanfaatan rumput laut (Eucheuma cottonii) untuk meningkatkan kadar iodium dan serat pangan pada 
selai dan dodol. Jurnal Teknologi dan Industri Pangan 15,61-69.

BSN. 1992. SNI 01-2986-1992 Syarat Mutu Dodol. Pusat Standarisasi Industri. Departemen perindustrian. Jakarta.

Chuah T.G., Nisah H. Hairul., Thomas Choong S.Y., Chin N.L., and Nazimah Sheikh A.H. 2006. Effects of temperature on viscosity of dodol (concoction). Journal of Food Engineering 80, 423-430.

Cooksley VG (2007) Seaweed. New York: Harry N. Abrams, Inc.

Nasaruddin F. , N.L. Chin \& Y.A. Yusof (2012) Effect of Processing on Instrumental Textural Properties of Traditional Dodol Using Back Extrusion, International Journal of Food Properties 15, 495-506.

Gamman, P.M. and K.B. Sherington, 1994. IImu Pangan. Nutrisi dan Mikrobiologi. Edisi ke-2. Diterjemahkan oleh Gardjito, M., Naruki, S., Murdiati, A dan Sardjono. Universitas Gadjah Mada. Yogyakarta.

Hartati, E. 1996. Pengembangan Teknologi Proses Pembuatan Dodol Makanan Tradisional Sulawesi Tengah. Departemen Prindustrian BPPI.

Kementerian Kelautan dan Perikanan (KKP). 2012. Statistik Perikanan Budidaya Indonesia 2012. Jakarta.

Martos, M., Y. Ruiz and J. Fernandez. 2011. Effect of Packaging Conditiontis on Shelf-Life of Mortadella Made With Citrus Fibre Washing Water And Thyme or Rosemary Essential Oil. Agrofood Tecnology Department. Miguel Hernandez University.

Mithril C, Dragsted L. O., Meyer, Tetens Inge, Jensen A.B and Astrup A. (2012). Dietary composition and nutrient content of the New Nordic Diet. Public Health Nutrition. 16,777-785.

Sembiring, 2002. Pemanfaatan Rumput Laut Eucheumacottonii sebagai Bahan Baku dalam Pembuatan Permen Jelly. Fakultas Teknologi Pertanian. IPB Bogor.

Sudarsono, 1981. Mempelajari Berbagai Jenis dan Sifat Pangan Semi Basah Tradisional dan Hubungannya dengan Keawetan. Skripsi. Jurusan Teknologi Pangan dan Gizi, Fakultas Teknologi Pertanian, Institut Pertanian Bogor, Bogor.
Sudarmadji, S., B. Haryono, dan Suhardi. 2003. Analisa Bahan Makanan dan Pertanian. Liberty. Yogyakarta.

Tamaheang, T., D.M. Makapeduadan S. Berhimpon. 2017. Kualitas Rumput Laut Merah (Kappa phycusalvarezii) dengan Metode Pengeringan Sinar Matahari dan Cabinet Dryer serta Rendemen SemiRefined Carrageenan. Jurnal Media Teknologi Hasil Perikanan 5, 152-157. 